\title{
NEOCONSERVADORISMO NO CAMPO DA EDUCAÇÃO (2002-2019): ANÁLISE BIBLIOMÉTRICA
}

\author{
Neoconservatism in the educational field (2002-2019): bibliometric analysis
}

\author{
El neoconservadurismo en el ámbito de la educación (2002-2019): análisis \\ bibliométrico
}

João Henrique da Silva*

\begin{abstract}
Resumo
Este estudo teve por objetivo identificar e caracterizar a produção científica, em especial brasileira, consolidada em artigos científicos, teses e dissertações acadêmicas sobre o neoconservadorismo no campo da educação. Sustentada em Antonio Gramsci, trata-se de uma pesquisa quanti-qualitativa, que fez uso da abordagem bibliométrica e análise de conteúdo a partir dos trabalhos coletados em seis bancos de dados. O corpus documental constitui-se de 38 trabalhos - 27 artigos, nove dissertações e duas teses - publicados entre 2002-2019, por 53 autores, com 57 contribuições e participação significativa do sexo masculino. A maioria dos estudos são do Brasil, de língua portuguesa. As autorias, em suas grande parte, foram individuais e contaram com diversas instituições de ensino das regiões brasileiras, com maior incidência da Região Sudeste. Os trabalhos fazem parte de estudos e periódicos na área da Educação, embora teve presença das áreas de Serviço Social, Sociologia e entre outras. Os temas dos trabalhos dedicaram-se prioritariamente na compreensão do neoconservadorismo no campo educacional, discutindo desde as políticas até as práticas pedagógicas. Conclui-se que neoconservadorismo é um fenômeno atual na realidade brasileira, devido a revolução passiva realizada no Estado, o qual sofreu influências nas elaborações e implementações de políticas educacionais.
\end{abstract}

PALAVRAS-CHAVE: Neoconservadorismo. Educação. Análise bibliométrica.

\begin{abstract}
This study aimed to identify and characterize the scientific production, Brazilian in particular, consolidated in scientific articles, theses and dissertations about neoconservatism in the educational field. It is a quantitative-qualitative research, sustained in Antonio Gramsci, that made use of both the bibliometrics approach and content analysis from the works collected in six data bases. Documentary corpus is made of 38 works - 27 articles, nine dissertations and two theses - published between 2002-2019, by 53 authors, with 57 contributions and significant participation of male authors. Most studies are from Brazil, written in Portuguese language. Authorships, in their majorities, were individual and relied upon diverse teaching institutions of Brazilian regions, with a higher occurrence in Southeast Region. The works are part of studies and journals in the educational area, even though areas such as Social Service, Sociology, among others were present. Work themes were focused primarily on the comprehension of
\end{abstract}

\footnotetext{
* Doutor em Educação Especial pela Universidade Federal de São Carlos. Professor visitante do Programa de Pós-Graduação em Educação da Universidade Federal de Roraima (PPGE/UFRR). Editor Adjunto da Revista Educação, Pesquisa e Inclusão. E-mail: jhsilvamg@icloud.com Orcid: https://orcid.org/00000003-0277-0466
} 
neoconservatism in the educational field, discussing from policies to pedagogical practices. We can conclude that neoconservatism is a current phenomenon in Brazilian reality due to the passive revolution carried in the State, which was influenced in elaborations and implementations of educational policies.

KEYWORDS: Neoconservatism. Education. Bibliometric analysis.

\section{Resumen}

Este estudio tuvo como objetivo identificar y caracterizar la producción científica, especialmente brasileña, consolidada en artículos científicos, tesis y disertaciones académicas sobre el neoconservadurismo en el ámbito de la educación. Apoyada en el pensamiento de Antonio Gramsci, se trata de una investigación cuantitativa y cualitativa, que utilizó el enfoque bibliométrico y el análisis de contenido de las obras recogidas en seis bases de datos. El corpus documental consta de 38 trabajos -27 artículos, nueve disertaciones y dos tesis- publicados entre 2002 y 2019, por 53 autores, con 57 contribuciones y una participación significativa de hombres. La mayoría de los estudios son del Brasil de la lengua portuguesa. La mayoría de los tipos de autores eran individuales y los estudios también tuvo la participación de varias instituciones educativas de las regiones brasileñas, con una mayor incidencia de la región Sudeste. Los trabajos forman parte de estudios y publicaciones periódicas en el área de la Educación, aunque tuvo presencia de las áreas de Servicio Social, Sociología y entre otras. Los temas de las obras se dedicaron principalmente a la comprensión del neoconservadurismo en el ámbito de la educación, discutiendo desde las políticas hasta las prácticas pedagógicas. Se concluye que el neoconservadurismo es un fenómeno actual en la realidad brasileña, debido a la revolución pasiva llevada a cabo en el Estado, que sufrió influencia en la elaboración y aplicación de las políticas educativas.

PALABRAS CLAVE: Neoconservadurismo. Educación. Análisis bibliométrico

\section{INTRODUÇÃO}

As políticas educacionais brasileiras sofrem interferências de agendas neoliberais de longa data. Os pesquisadores estão buscando compreender o porquê em pleno século XXI ainda há discursos políticos que pedem o resgate aos valores tradicionais, da família, da moral e da nação. Em tempos de globalização e avanço tecnológico, certos grupos da sociedade civil tem apregoado um discurso contra a pauta da diversidade humana, sexual e étnica-racial e, ao mesmo tempo, proposto a militarização, a redução da maioridade penal, o nacionalismo exacerbado, a educação neutra política e ideologicamente como remédios à "desordem social". Há vários fatores que interferem e influenciam tal conjectura social, cultural e política. Esses fatores têm levado grupos neoconservadores da sociedade civil a posturas extremistas e a proposituras de legislações que dizem defender a liberdade da família e da religião, bem como a instauração de uma nova ordem e progresso no país. Uma nova sociedade que se alicerçaria na tríade Deus, Família e Nação.

Diante desse cenário conflituoso e contraditório, é preciso conceituar o movimento conservador para entender o neoconservadorismo. $\mathrm{O}$ movimento conservador, ao longo do século XX, teve o objetivo de "preservar, proteger e defender" as culturas e instituições sociais, econômicas e políticas existentes (HUNTINGTON, 1999; TEIXEIRA, 2007; MOLL, 2015).

De acordo com Huntington (1999), 


\begin{abstract}
Conservatism has appeared as an intellectual and political movement at various times in the history of the West: in Europe in the sixteenth and seventeenth centuries against the threats the rising absolute monarchies posed to medieval pluralism; in England at the end of the sixteenth century in response to the challenge the rise of Puritanism was posing to the existing church-state establishment; in much of Europe at the end of the eighteenth century in response to the threat posed by the French Revolution and its accompanying movements; and in nineteenth-century Europe in response to the demands for suffrage by first middle-class and then working-class movements [...]. What has been called conservatism in America is very different. It is a conservative form of liberalism, opposed to popular or democratic liberalism. It has been assigned many labels, including "Whiggery" by Louis Hartz and "market conservatism" by a perceptive Russian analyst. It is, however, perhaps best termed doctrinal conservatism. This conservatism is identified with the promotion of commerce and industry, laisser faire capitalism, private enterprise, and a minimal role for government ${ }^{1}$.
\end{abstract}

Após a Segunda Guerra Mundial, em especial, durante a Guerra Fria e as décadas de 1960, o movimento conservador é reatualizado em conformidade com as dinâmicas do modo de produção capitalista, da globalização e do avanço tecnológico (APPLE, 2003; MOLL, 2015; LIMA; HYPOLITO, 2019).

Para Prendergast, Hill e Jones (2017), o neoconservadorismo consiste em primeiro lugar, na hierarquia, ordem e controle e, em segundo lugar, na moralidade tradicional. Segundo Lima e Hypolito (2019), os neoconservadores constitui um dos grupos que compõem a Nova Direita. Este conceito passou a ser utilizado na literatura estadunidense, especificamente, e europeia para designar um movimento que teve início por volta dos anos de 1960 (APPLE, 2003; LIMA; HYPOLITO, 2019). Um movimento que reúne o grupo de neoconservadores e neoliberais que visaram o desmantelamento do Estado de Bem-Estar Social e a criação de uma nova forma de administrar o Estado, principalmente em virtude da crise do capital dos anos de 1970 (LIMA; HYPOLITO, 2019).

Para Moll (2015, p. 1), o "neoliberalismo e neoconservadorismo são percepções de mundo gestadas em trajetórias diferentes que ganharam forma na segunda metade da década de 1970, momento de crise e, por conseguinte, de reforma do capitalismo". Os neoconservadores concordam com o modelo de um Estado Mínimo, mas diferente do neoliberalismo em relação aos direitos civis, políticos e sociais, eles resgataram do tradicionalismo a ênfase moral (LIMA; HYPOLITO, 2019).

\footnotetext{
${ }^{1}$ Tradução livre: "O conservadorismo apareceu como um movimento intelectual e político em vários momentos da história do Ocidente: na Europa, nos séculos XVI e XVII, contra as ameaças que as crescentes monarquias absolutas representavam ao pluralismo medieval; na Inglaterra, no final do século dezesseis, em resposta ao desafio que a ascensão do puritanismo estava colocando no estabelecimento de estado da igreja existente; em grande parte da Europa, no final do século XVIII, em resposta à ameaça representada pela Revolução Francesa e seus movimentos associados; e na Europa do século XIX, em resposta às demandas de sufrágio dos movimentos da classe média e da classe trabalhadora [...]. O que tem sido chamado conservadorismo na América é muito diferente. É uma forma conservadora de liberalismo, em oposição ao liberalismo popular ou democrático. Ele recebeu vários selos, incluindo "Whiggery", de Louis Hartz, e "conservadorismo de mercado", de um analista perspicaz russo. É, no entanto, talvez melhor denominado conservadorismo doutrinário. Esse conservadorismo é identificado com a promoção do comércio e da indústria, do capitalismo da liberdade total, da iniciativa privada e do Estado mínimo" (HUNTINGTON, 1999).
} 
Como ensina Moll (2015),

\begin{abstract}
Nos anos 1960 e 1970, a desilusão com o liberalismo estadunidense e com o conservadorismo moderado somada à oposição ao comunismo promoveu uma nova geração de conservadores, que mesclavam os ideais do liberalismo clássico com uma perspectiva moral da sociedade. Os neoconservadores e o neoconservadorismo partiam do mesmo princípio dos neoliberais, acreditando que a interferência do governo na economia e os programas sociais geravam inflação, endividamento, prejuízos à produtividade e, mais do que isso, desestimulavam o trabalho e a inovação. Portanto, afetavam a produtividade e enfraqueciam o país. Acima de tudo, o Estado teria passado a perseguir um igualitarismo pervertido e abstrato e para isso usurpou o lugar da família, da igreja e da comunidade, enfraquecendo esses laços supostamente naturais. Como consequência, os jovens passaram a valorizar a leniência, a dependência, o consumo de drogas, a pornografia e o sexo. Isso teria aumentado a criminalidade e enfraquecido os Estados Unidos. Desse modo, os problemas morais derivavam do Estado totalizante (liberal ou comunista). Por isso, além de medidas econômicas, seria necessário reforçar os valores clássicos ocidentais para prover a base normativa para os Estados democráticos, liderados por homens capazes e ilibados. (MOLL, 2015, p. 34).
\end{abstract}

Desse modo, pode-se compreender que o neoconservadorismo se forma a partir de dois elementos contraditórios: 1 . a contextualização do movimento conservador; 2 . a incorporação de ideias libertárias, mas enfatizada no indivíduo e na livre economia. Tal ênfase se aproxima muito dos pressupostos neoliberais. Ao mesmo tempo que os neoconservadores apregoam uma moral calcada na família e na religião, defendem também o indivíduo e a sua capacidade de escolha. (MOLL, 2015; HYPOLITO, 2019).

As ideias neoconservadoras chegaram rapidamente no Brasil por meio dos meios de comunicação em massa, intelectuais e políticos (MOLL, 2015). Nessa esteira, o país presenciou o movimento de oposição ao governo de Dilma Rousseff (2010-2016) e o seu impeachment, o movimento Escola Sem Partido (2014-), a construção do novo Plano Nacional de Educação (2014-2024) e da Base Nacional Curricular Comum (20132018), a contrarreforma do ensino médio imposto pela Lei $13.415 / 2017$, a PEC 55/16 promulgada como Emenda Constitucional n. ${ }^{\circ}$ 95/2016 e as eleições presidenciais de 2018 (MOLL, 2015; LEHER, VITTÓRIA; MOTTA, 2017; SILVA, M. 2017; GOULART DA SILVA, 2019; LIMA; HYPOLITO, 2019; SILVA, 2019). Não podemos esquecer das mobilizações sociais que surgiram nas manifestações de junho de 2013 que tiveram adesão de várias pessoas, mas com pautas contraditórias, como se verá adiante.

Diante desse cenário político e educacional, diversos estudiosos debruçaram sobre a onda neoconservadora. Para Prendergast, Hill e Jones (2017), os principais aspectos do neoconservadorismo, relacionados à educação, podem ser vistos como:

1. Control of Curricula of schools, of teacher education and universities, with the removal of 'dangerous' content.

2. Control of Pedagogy teaching methods, pedagogic relations between teacher and students. 
3. Control of Students, through debt, and through actual or fear of unemployment.

4. Control of Teachers and Professors, through surveillance, a culture of having to meet targets, punishment of dissidents and union activists, dismissals and closures of schools, closures of university departments.

5. Brute force and 'the Security State' within schools and the wider societythe use of tear gas, sound grenades, stun grenades, beatings, prosecutions, draconian sentencing, and in some countries, imprisonment, killings ${ }^{2}$. (PRENDERGAST; HILL; JONES, 2017, p. 34).

Tendo presente essa conjectura social, política e educacional complexa, caracterizada por contradições e luta de classes, é necessário conhecer de que forma a produção científica reverberou esses acontecimentos que interferiram nas políticas e no cotidiano. Assim, cabe a seguinte pergunta: Como se configura a produção científica, em especial a brasileira, sobre o tema neoconservadorismo no campo da educação?

A pesquisa teve como objetivo identificar e caracterizar a produção científica, principalmente, localizadas no Brasil, consolidada em artigos científicos, teses e dissertações acadêmicas sobre o referido tema, em relação aos seguintes parâmetros bibliométricos:

1. Em artigos científicos: perfil dos periódicos, distribuição temporal dos artigos, autoria, gênero, área de formação acadêmica, tipos de autoria, instituição de ensino vinculada e palavras-chaves.

2. Em teses e dissertações: perfil dos autores e orientadores, distribuição temporal e nível do trabalho (mestrado/doutorado); instituição de ensino superior (IES), programa de pós-graduação e área de conhecimento, palavras-chaves.

O presente estudo possibilita mapear e conhecer a produção científica sobre o neoconservadorismo no campo educacional, pois oferece um perfil das pesquisas acadêmicas que se dedicam a refletir sobre esse tema que tem sido tão discutido em fóruns, congressos e eventos. Além fornecer elementos para compreender quais são os temas discutidos nas pesquisas analisadas. O próximo tópico apresenta a fundamentação teórica que norteou a discussão dos dados, por meio do qual foram utilizados conceitos gramscianos para melhor compreensão da realidade material e objetiva. Em seguida, descrevo o método empregado. Posteriormente, exponho o mapeamento da produção, considerando os parâmetros bibliométricos, seguido da análise dos temas dos trabalhos.

\section{Fundamentação teórica}

\footnotetext{
2 “1. Controle de currículos de escolas, de formação de professores e universidades, com a remoção de conteúdo 'perigoso'. 2. Controle dos métodos de ensino de Pedagogia, e das relações pedagógicas entre professor e alunos. 3. Controle dos estudantes, por meio da dívida e do medo do desemprego. 4. Controle de professores da educação básica e professores universitários, através da vigilância, de uma cultura de ter que cumprir metas, além de punição de dissidentes e ativistas sindicais, demissões e fechamentos de escolas, e fechamentos de departamentos universitários. 5. Emprego da força bruta e do "Estado de Segurança" [Doutrina de Segurança Nacional] nas escolas e na sociedade em geral - uso de gás lacrimogêneo, granadas sonoras, granadas de efeito moral, espancamentos, processos, sentenças draconianas e, em alguns países, prisão, assassinatos etc." (Tradução livre). (PRENDERGAST; HILL; JONES, 2017, p. 34).
} 
Antonio Gramsci (1891-1937) é um teórico do pensamento marxiano que pode nos auxiliar na tarefa de compreender o cenário político e educacional brasileiro, por meio dos conceitos de: homem, senso comum, ideologia, hegemonia, intelectuais orgânicos, sociedade civil, sociedade política, Estado, bloco histórico, partido e revolução passiva.

Para Gramsci, o homem “[...] essencialmente 'político', já que a atividade para transformar e dirigir conscientemente os outros homens realiza sua 'humanidade' e a sua "natureza humana"' (2014, p. 407). Mas ele não se concebe isoladamente. O homem está repleto "[...] de possibilidades oferecidas pelos outros homens e pelas sociedades das coisas, da qual não pode deixar de ter um certo conhecimento" (GRAMSCI, 2014, p. 415).

Nessa esteira, o homem possui diversas concepções de mundo (GRAMSCI, 2014). Há várias formas de concepção de mundo, que pode aparecer de duas maneiras: a) ocasional e desagregado; b) coerente e homogêneo. A primeira maneira se refere ao senso comum, à religião popular e ao folclore. Já a segunda maneira é "[...] formada de uma maneira crítica e consciente, num processo teórico-prático que tem como fundamento último a experiência política da classe" (MOCHOCOVITCH, 1992, p. 15). Esta concepção se chama de filosofia, em especial, Gramsci defende a filosofia da práxis, entendida como o materialismo histórico e dialético, elaborado por Marx e Engels.

O senso comum é um nome coletivo, porque não existe um único senso comum. Este também é um produto e um devir histórico. Ele "[...] é um produto sócio-histórico, capaz de garantir a manutenção da direção e da dominação presente na formação econômica e social, mediante a orientação que dá ao desenvolvimento da moralidade individual e coletiva" (MARTINS, 2005, p. 145). O senso comum causa um conformismo ativo nas classes subalternas, que incide na conformidade com a hegemonia do grupo dirigente e dominante, que traduz, na prática sócio-histórica, pela passividade e pela indiferença (MARTINS, 2005).

O senso comum pode ser utilizado para construir uma ideologia, que está presente em toda as manifestações de vida individuais e coletivas (GRAMSCI, 2014). A ideologia é uma concepção de mundo transformada em vontade, a ponto de dirigir o pensamento, o sentimento e a ação do sujeito. Ela "[...] tem uma existência material, encontra-se materializada nas práticas, é 'constituidora do real"' (BRANDÃO; DIAS, 2007, p. 92-93).

É importante diferenciar as ideologias historicamente orgânicas das ideologias arbitrárias, racionalísticas [sic], "voluntaristas", "desejadas". As ideologias historicamente orgânicas são responsáveis, por meio do discurso apropriado, mobilizar, articular e direcionar as ações das classes (BRANDÃO; DIAS, 2007). Elas são necessárias a uma determinada estrutura, “[...] elas 'organizam' as massas humanas, formam o terreno no qual os homens se movimento, adquirem consciência de sua posição, lutam [...]" (GRAMSCI, 2014, p. 237). Já as ideologias "arbitrárias" criam apenas "movimentos" individuais, polêmicas (GRAMSCI, 2014).

As ideologias são fundamentais na luta de classe, porque elas podem se tornar hegemônicas, fazer parte da vontade coletiva organizada em torno de um projeto (visão de mundo) (BRANDÃO; DIAS, 2007). A hegemonia opera “[...] não apenas sobre a estrutura econômica e sobre a organização política da sociedade, mas também sobre o 
modo de pensar, sobre as orientações ideológicas e inclusive sobre o modo de conhecer" (GRUPPI, 1980, p. 3).

\title{
O exercício da hegemonia
}

\begin{abstract}
[...] caracteriza-se pela combinação da força e do consenso, que se equilibram de modo variado, sem que a força suplante muito o consenso, mas, ao contrário, tentando fazer com que a força pareça apoiada no consenso da maioria, expresso pelos chamados órgãos de opinião pública - jornais e associações - os quais, por isso, em certas situações, são artificialmente multiplicados (GRAMSCI, 2007, p. 95).
\end{abstract}

Para a hegemonia ser consolidada, ela necessita dos intelectuais que, geralmente, estão a serviço da classe fundamental burguesa. Os intelectuais atuam como organizadores da hegemonia e funcionários da superestrutura.

Para Gramsci (2001), os intelectuais possuem uma relação mediatizada em diversos graus em todo o tecido social. Eles contribuem na luta de classes para que seu grupo seja favorecido, visto que possuem todo um aparato que permite exercer a sua função de direção e intermediário nas decisões. Os intelectuais têm a responsabilidade de ser o organizador e formulador de uma ideologia que sedimenta o seu grupo social no modo de produção. Eles são responsáveis pela conquista da hegemonia social e política. (GRAMSCI, 2001).

Gramsci (2001) considera dois tipos de intelectuais presentes na sociedade capitalista, o intelectual tradicional e o intelectual orgânico. Os intelectuais tradicionais são os intelectuais rurais que provém da burguesia rural absenteísta, como o clero, advogados, tabeliões (GRUPPI, 1980). Os intelectuais orgânicos são formados no âmbito das relações hegemônicas. Eles podem ser da burguesia ou do proletariado. "Eles expressam, organizam, defendem, os objetivos e interesses do grupo social ao qual estão vinculados" (SCHLESENER, 2001, p. 27).

O termo orgânico, em Gramsci, é "[...] o compromisso vital que os intelectuais podem ter com as classes no processo que travam na disputa pela hegemonia em uma totalidade sócio-histórica [...]" (MARTINS, 2011, p. 144).

Cabe aos intelectuais orgânicos " [...] organizar a economia, a política, a cultura, divulgar concepções de mundo, construir as bases para a formação do 'consentimento', viabilizando o exercício da hegemonia" (SCHLESENER, 2001, p. 28). Esse intelectual pode fazer parte da classe econômica e politicamente dominante (GRUPPI, 1980).

Assim sendo, os intelectuais orgânicos, como elaboradores da hegemonia e mediadores entre a sociedade civil e sociedade política, ocupam função significativa nos partidos políticos que, por sua vez, procuram criar os seus próprios intelectuais. $\mathrm{O}$ partido é um "[...] organismo criado pelas próprias massas como instrumento de luta e de autoeducação de elaboração e difusão de uma nova concepção de mundo" (SCHLESENER, 2001, p. 29). Ele pode desenvolver uma nova vontade política, por meio dos intelectuais que podem assumir uma função estatal (GRUPPI, 1980).

Estado, para Gramsci (2007, p. 41-42) é um 
[...] organismo próprio de um grupo, destinado a criar as condições favoráveis à expansão máxima desse grupo, mas este desenvolvimento e esta expansão são concebidos e apresentados como a força motriz de uma expansão universal, de um desenvolvimento de todas as energias "nacionais" isto é, o grupo dominante é coordenado concretamente com os interesses gerais dos grupos subordinados e a vida estatal é concebida como uma contínua formação e superação de equilíbrios instáveis (no âmbito da lei) entre os interesses do grupo fundamental e os interesses dos grupos subordinados, equilíbrios em que os interesses do grupo dominante prevalecem, mas até um determinado ponto, ou seja, não até o estreito interesse econômico-corporativo.

Conforme Gramsci, o Estado não é uma superestrutura em si. Ele é constituído por um grupo dominante que, ao mesmo tempo, domina e dirige de acordo com os seus interesses. O Estado também leva em consideração os interesses gerais dos subordinados para conseguir permanecer no comando. A gestão do Estado é marcada por disputas, buscando utilizar os mecanismos de consenso para atender os interesses dos grupos subordinados.

A configuração do Estado decorre do fato de que ele incide no poder exercido por meio da sociedade política e sociedade civil (GRAMSCI, 2007, 2011). O Estado não se reduz à sociedade política, pelo contrário, a sociedade civil é imanente e confere hegemonia ao Estado.

A sociedade civil diz respeito a um conjunto de instituições, que chamadas de 'privadas', são relativamente autônomas em relação à sociedade política, ou mesmo surgem com esta função com as revoluções democrático-burguesas (SCHLESENER, 2001). A sociedade civil elabora e difunde as concepções de mundo da classe dominante, procurando permanecer na direção política e cultural da sociedade. Em síntese, a sociedade civil é formada pelas instituições - como a escola, a Igreja, os sindicatos, as corporações profissionais - que elaboram e/ou divulgam as ideologias, as quais possibilitam a formação de consenso (SCHLESENER, 2001; GRAMSCI, 2007, 2011).

A sociedade política é composta por aparelhos administrativo-burocrático e político-militar, mediante os quais a classe que detém o poder tem condições de disciplinar e reprimir os grupos sociais que são contra o seu domínio (SCHLESENER, 2001). A sociedade política é "[...] uma extensão da sedimentação ideológica promovida pela sociedade civil, que se expressa por meio dos aparelhos e atividades coercitivas do Estado, visando adequar as massas à ideologia e à economia dominante" (MARTINS, 2008, p. 83).

No exercício do poder, a sociedade política tem "domínio direto" ou o comando do Estado. Ela "[...] tem a função de controlar, de 'assegurar legalmente a disciplina dos grupos que não consentem, nem ativa, nem passivamente' aos objetivos dominantes; a coerção é exercida principalmente nos momentos de crise, quando fracassa o consenso espontâneo" (SCHLESENER, 2001, p. 19).

Os aparelhos da sociedade civil e sociedade política, mediado por intelectuais comprometidos com a manutenção do modelo de vida capitalista, propiciam a conformação do "bloco histórico". Este é formado pelo conjunto complexo e contraditório das relações entre estrutura e a superestrutura (GRAMSCI, 2014). O "bloco histórico" assegura a hegemonia da classe dominante economicamente e 
dirigente sob o ponto de vista ético-político. E isso é possível por meio do uso dos aparelhos de "convencimento" da sociedade civil e de coerção da sociedade política, que são mediados por diferentes atores sociais comprometidos com a conservação da realidade (MARTINS, 2008).

A revolução passiva também é uma estratégia da classe burguesa, pois “[...] as grandes massas populares não são o sujeito e os protagonistas, mas antes o objeto dos eventos históricos, as massas populares são arrastadas pela hegemonia de classes desligadas dos interesses dos estratos populares mais profundos" (GRUPPI, 1980, p. 84).

\section{Método}

De acordo com Gramsci (2014), a ciência não tem verdades científicas definitivas e peremptórias. A ciência é uma categoria histórica, um movimento em contínua evolução. Ela está relacionada às necessidades, à vida e à atividade do homem. Por isso, o trabalho científico tem dois aspectos principais: a) um retifica constantemente o modo do conhecimento, "[...] retifica e reforça os órgãos sensoriais, e elabora princípios novos e complexos de indução e dedução, ou seja, aperfeiçoa os próprios instrumentos de experiência e de sua verificação"; b) outro que aplica esse "[...] complexo instrumental para determinar, nas sensações, o que é necessário e o que é arbitrário, individual, transitório" (GRAMSCI, 2014, p. 173).

Nesse sentido, a atividade científica de analisar as pesquisas tem a tarefa de compreender as possibilidades, os avanços e os desafios de outros estudos. $\mathrm{Na}$ área da Educação, a análise da produção acadêmica tornou-se uma ferramenta importante para acompanhar o seu desenvolvimento. As pesquisas já produzidas podem nos auxiliar na compreensão das investigações realizadas sobre o neoconservadorismo e sua relação com a educação.

Com o objetivo de cumprir essa tarefa, esta pesquisa ancora-se na perspectiva quanti-qualitativa, utilizando como procedimento a adoção das abordagens bibliométrica e da análise de conteúdo. Do ponto de vista metodológico, a perspectiva quantitativa e qualitativa são natureza diferente, mas "do ponto de vista epistemológico, nenhuma das duas abordagens é mais científica do que a outra" (MINAYO; SANCHES, 1993, p. 247). E concordo com Minayo e Sanches quando dizem que "[...] tanto do ponto de vista quantitativo quanto do ponto de vista qualitativo, é necessário utilizar todo o arsenal de métodos e técnicas que ambas as abordagens desenvolveram para que fossem consideradas científicas" (1993, p. 247). Compreendo que as análises quantitativas e qualitativas estão articuladas dentro de uma totalidade, que podem ser as produções acadêmicas disseminadas e produzidas na pós-graduação, bem como aquelas publicadas nos periódicos.

A Bibliometria pauta-se pelo princípio de analisar a atividade científica ou técnica pelos estudos quantitativos das publicações (HAYASHI; MUGNAINI; HAYASHI, 2013). Para Tannuri de Oliveira e Gracio (2013, p. 76),

os estudos bibliométricos constituem um método de abordagem para análise e avaliação da produção científica e contribuem para a visualização do comportamento da ciência em um dado campo. A partir desses indicadores pode-se sinalizar o que é mais importante ou significativo dentro de um campo ou um contexto científico, por meio da análise das suas tendências. 
Já a análise de conteúdo tem se revelado um método eficaz para complementar os estudos bibliométricos, pois permite extrair o sentido dos textos por meio de unidades e categorias de análise (SILVA; HAYASHI, 2018; SILVA, J. 2017).

Sobre a seleção dos fontes deste estudo, em conformidade com Stelmachuk e Hayashi (2015), o corpus de uma pesquisa composto por artigos publicados em periódicos científicos e teses e dissertações defendidas em programas de pós-graduação do Brasil, trata-se de uma escolha baseada

[...] no reconhecimento da importância desse corpus enquanto conhecimento científico validado pelos pares, tanto no julgamento perante uma banca examinadora, quanto no sistema de peer review adotado pelos periódicos- e de sua contribuição para a produção de conhecimento no âmbito da pesquisa e da pós-graduação (STELMACHUK; HAYASHI, 2015, p. 36).

Penso que o corpus documental constitui uma realidade material, com múltiplas determinações, que requerem uma abstração. Mediante a abstração do concreto produção científica disseminada em periódicos e defendidas em pós-graduação possibilita compreender o dinamismo da pesquisa sobre a neoconservadorismo no Brasil e suas implicações ou relações na área da Educação. Portanto, este artigo vinculase a esses procedimentos - bibliometria e análise de conteúdo - para captar o real e atingir os objetivos da presente pesquisa.

Essas perspectivas propiciaram a coleta e o registro dos dados, por meio da busca de estudos com as seguintes expressões, "neoconservadorismo" e "educação". As produções foram coletadas em seis bancos de dados, a saber: Biblioteca Digital de Teses e Dissertações do Instituto Brasileiro de Informação para Ciência e Tecnologia do Ministério da Ciência, Tecnologia e Inovação (BDTD, IBICT, MCT), Catálogo de Teses e Dissertações Capes/MEC, OasisBr do IBICT ${ }^{3}$, biblioteca Scientific Eletronic Library Online (SciELO), Portal de Periódicos Capes/MEC e Red de Revistas Científicas de América Latina y el Caribe, España y Portugal (Redalyc) ${ }^{4}$. Esses bancos de dados possibilitam colher documentos produzidos, por meio de categorização e refinamentos na busca no mês de abril de 2020. O recorte temporal não foi pré-definido, almejando realizar o mapeamento da evolução da produção científica sobre neoconservadorismo e educação.

Tendo em vista que a expressão apresentou muitos resultados, foi definido como critério de inclusão as produções que abordam o neoconservadorismo no campo da educação. Para isso, recorri as leituras dos títulos, dos resumos e das palavras-chaves que proporcionaram verificar a presença ou ausência do enfoque sobre $o$ neoconservadorismo na área educacional. Quanto aos critérios de exclusão, foram excluídos trabalhos com registros duplicados, já coletados em outro banco de dados, ou ainda que são produções sobre neoconservadorismo que não estavam dentro do campo educacional. A partir desses critérios, foram identificadas várias produções da biblioteca

\footnotetext{
3 “O Portal brasileiro de publicações científicas em acesso aberto - oasisbr é um mecanismo de busca multidisciplinar que permite o acesso gratuito à produção científica de autores vinculados a universidades e institutos de pesquisa brasileiros. Por meio do oasisbr é possível também realizar buscas em fontes de informação portuguesas" (IBICT, 2020a).

${ }^{4} \mathrm{Na}$ Redalyc selecionei estudos direcionados para área da educação, por meio do filtro disponibilizado, pois isso atende ao princípio de objetividade da bibliometria e ao interesse desta pesquisa.
} 
SciELO que já tinham sido contempladas na Redalyc e Portal Periódico da Capes, consequentemente, trabalhos duplicados foram descartados.

Cumpre registrar que encontrei muitos trabalhos em outras áreas de conhecimento, mas que não faziam referência ao campo da educação, consequentemente, foram excluídos. Porém, considero que são produções que podem servir em outras investigações na tarefa de mapear toda a produção sobre o tema neoconservadorismo, independente da área de conhecimento.

Os textos coletados foram inseridos em dois protocolos de registro bibliométricos elaborados por Hayashi (2014) e construídos com o auxílio do software Excel, que apresentava os seguintes campos, de acordo com o tipo de documento: a) artigos: expressão de busca; base de dados, idioma, nome do(s) autor(es), gênero dos autores, área formação dos autores e instituição, tipos de autoria, título do artigo, título do periódico, ano de publicação, resumo, objetivo, palavras-chaves; b) teses e dissertações: expressão de busca; autor; gênero do autor; orientador; gênero do orientador; título do trabalho; ano de defesa; nível (mestrado/doutorado); instituição de ensino superior; programa de pós-graduação; região do país; resumo; objetivos da pesquisa; palavras-chaves.

Dessa maneira, o corpus documental resultou em 38 estudos publicados entre 2002 a 2019. A tabela 1 expõe a quantidade de estudos por banco de dados, já com os critérios de inclusão e exclusão aplicados. A Redalyc apresenta a maior parte da produção significativa. Também indica que 11 estudos são teses e dissertações, o que equivalem a 30\%, ao passo que 17 estudos são artigos científicos, representando $70 \%$ da produção total. Isto é, o tema neoconservadorismo encontra-se, majoritariamente, divulgado em periódicos.

Tabela 1 - Distribuição dos trabalhos por bancos de dados

\begin{tabular}{|c|c|c|}
\hline BANDOS DE DADOS & QUANTIDADE & $\begin{array}{c}\text { EQUIVALENCIA } \\
\mathbf{( \% )}\end{array}$ \\
\hline $\begin{array}{c}\text { BIBLIOTECA DIGITAL DE TESES E } \\
\text { DISSERTAÇÕES }\end{array}$ & 5 & $13 \%$ \\
\hline $\begin{array}{c}\text { CATÁLOGO DE TESES E } \\
\text { DISSERTAÇÕES }\end{array}$ & 6 & $17 \%$ \\
\hline OASISBR & 5 & $13 \%$ \\
\hline PORTAL DE PERIÓDICOS & 4 & $10 \%$ \\
\hline REDALYC & 18 & $47 \%$ \\
\hline TOTAL & 38 & $100 \%$ \\
\hline
\end{tabular}

Fonte: IBICT, 2020a, 2020b; CAPES, 2020a, 2020b; Redalyc, 2020. Elaboração do autor.

Tendo em vista a necessidade de compreender os resultados obtidos na pesquisa sobre a produção científica sobre neoconservadorismo na área educacional, optei por apresentar os resultados obtidos organizados em dois tópicos: o primeiro oferece um panorama bibliométrico dessa produção, já o segundo apresenta e discute os temas das produções.

\section{Panorama bibliométrico da produção científica}


Os seis bancos de dados constituíram um corpus documental de 38 produções duas teses, nove dissertações e 27 artigos - publicados entre o período de 2002-2019. As produções foram elaboradas por 53 autores - dois trabalhos defendidos para o título de doutor e nove para o título de mestre, e mais 42 autores de artigos - que totalizam 57 contribuições ${ }^{5}$. Nenhuma produção de tese e dissertação foi publicada em formato de artigo. No levantamento de artigos verifiquei que somente quatro autores contribuíram duas vezes cada, a saber: Ivany Rodrigues Pino, Luana Costa Almeida, Sandra Escovedo Selles, Theresa Adrião. Representa, assim, que há um número significativo de autores que mencionaram e/ou trabalharam o neoconservadorismo no campo educacional em seus escritos, porém, sinaliza que não há uma rede de colaboração científica e um projeto de pesquisa sistematizado que aglutine vários pesquisadores. Inclusive, os produtos das pesquisas de programas de pós-graduação não foram socializados em revistas científicas indexadas nos bancos de dados que foram consultados. Talvez porque o foco destinado dessas produções não tem sido a área educacional, mas no campo das ciências humanas e sociais.

Os 42 autores dos artigos em sua maioria são homens ( $\mathrm{n}=27)$, enquanto mulheres $(\mathrm{n}=15)$ representam uma participação aproximada de 35\%. As 11 pesquisas foram produzidas por oito mulheres e três homens. Os 11 orientadores são nove mulheres e dois homens. No geral, temos 30 homens e 23 mulheres, a apontar que a participação de homem tem sido significativa no assunto sobre neoconservadorismo na área da Educação, assim, não foi confirmada a feminização de mulheres no campo da ciência da educação, constatada por Rigolin, Hayashi, Hayashi (2013).

À maioria dos trabalhos também são originários do Brasil $(n=34)$, com pouca participação de textos de Portugal $(n=3)$ e Colômbia $(n=1)$. Os 38 estudos foram escritos, à maioria, na língua portuguesa $(\mathrm{n}=37)$. Somente um estudo foi escrito em espanhol, dos autores Di Franco, Di Franco e Siderac (2016).

Em relação aos tipos de autorias dos artigos, uma parcela significativa do estudo foi produzida individualmente $(\mathrm{n}=15)$, o que equivale a 55,6\% escritos por um único autor. Seis artigos em dupla (22\%). Cinco trabalhos em trio (18\%). Somente houve um artigo com quatro autores. Assim, alta porcentagem de autores ocasionais nos periódicos mostra rarefação ou dispersão de estudos relacionados ao neoconservadorismo na educação.

No que concerne à distribuição temporal, os resultados indicaram um período de abrangência de 17 anos, compreendido entre 2002 a 2019 (tabela 2). O primeiro trabalho produzido foi em 2002. Houve ausência de publicação de trabalhos em 2005, 2007, 2008 e 2011. No ano de 2019 e 2010 houve três produções. E somente a partir de 2012 que a produção não é interrompida, com a média de três trabalhos por ano. A concentração dos trabalhos está entre 2016 a 2019 (n=24), o que equivale 63\%.

Aliás, as dissertações defendidas iniciaram-se em 2013, depois de 11 anos do primeiro artigo publicado, enquanto houve uma tese apresentada em 2004. A partir de 2013, as pesquisas de pós-graduação mantiveram a média anual de um trabalho por ano, porém, concentrou-se no biênio 2018-2019. Porém, cabe registrar que o total de teses $(n=2)$ é exíguo, e a distribuição anual está presente em 2004 e 2019, com um trabalho cada, em um intervalo de 15 anos.

\footnotetext{
${ }^{5}$ Há dupla contagem de autores no total de contribuições, uma vez que os autores publicaram em coautoria.
} 
Tabela 2 - Distribuição anual das dissertações, teses e artigos analisados

\begin{tabular}{|c|c|c|c|c|}
\hline ANO & DISSERTAÇ ÕES & TESES & ARTIGOS & TOTAL \\
\hline $\mathbf{2 0 0 2}$ & 0 & 0 & 1 & 1 \\
\hline $\mathbf{2 0 0 3}$ & 0 & 0 & 1 & 1 \\
\hline $\mathbf{2 0 0 4}$ & 0 & 1 & 1 & 2 \\
\hline $\mathbf{2 0 0 5}$ & 0 & 0 & 0 & 0 \\
\hline $\mathbf{2 0 0 6}$ & 0 & 0 & 1 & 1 \\
\hline $\mathbf{2 0 0 7}$ & 0 & 0 & 0 & 0 \\
\hline $\mathbf{2 0 0 8}$ & 0 & 0 & 0 & 0 \\
\hline $\mathbf{2 0 0 9}$ & 0 & 0 & 1 & 1 \\
\hline $\mathbf{2 0 1 0}$ & 0 & 0 & 2 & 2 \\
\hline $\mathbf{2 0 1 1}$ & 0 & 0 & 0 & 0 \\
\hline $\mathbf{2 0 1 2}$ & 0 & 0 & 1 & 1 \\
\hline $\mathbf{2 0 1 3}$ & 2 & 0 & 1 & 3 \\
\hline $\mathbf{2 0 1 4}$ & 0 & 0 & 1 & 1 \\
\hline $\mathbf{2 0 1 5}$ & 0 & 0 & 1 & 1 \\
\hline $\mathbf{2 0 1 6}$ & 1 & 0 & 5 & 6 \\
\hline $\mathbf{2 0 1 7}$ & 1 & 0 & 3 & 4 \\
\hline $\mathbf{2 0 1 8}$ & 3 & 0 & 2 & 5 \\
\hline $\mathbf{2 0 1 9}$ & 2 & 1 & 6 & 9 \\
\hline TOTAL & 9 & 2 & 27 & 38 \\
\hline
\end{tabular}

Fonte: Elaboração do autor.

A regularidade dos trabalhos a partir do ano de 2012 pode ser explicada por quatro fatores: Manifestações de junho de 2013, movimento Escola Sem Partido (ESP), Plano Nacional de Educação (PNE) 2014-2024 e a tramitação da Base Nacional Comum Curricular - BNCC (2013-2018). Trata-se de eventos que influenciaram na agenda educacional, sem desconsiderar as contrarreformas perpetradas pelo capital no Estado brasileiro e o golpe de Estado soft em 2016.

As Manifestações de junho de 2013 “"...] representaram tentativas espontâneas e difusas das classes trabalhadoras e demais classes subalternas de reivindicarem participação efetiva nos processos decisórios do país, em um cenário marcado por contradições de ordem conjunturais" (SILVA, M. 2017, p. 5). Contudo, essas manifestações expressavam contradições de ordem estruturais da formação social brasileira,

de um lado, o Estado autocrático brasileiro investindo bilhões de reais na construção de estádios de futebol, para a realização da Copa do Mundo de 2014, no e a partir do qual se instituiu o lema "padrão Fifa", como forma de se garantir luxuosas estruturas para o desfrute das classes dominantes mundiais, ao mesmo tempo, beneficiando as grandes empreiteiras brasileiras, no âmbito da construção civil, bem como a fração de classe hegemônica no bloco no poder, de caráter rentista-financista, tanto pela via da política 
monetária e fiscal, quanto pela via da especulação imobiliária direta e indireta produzida pelas obras. (SILVA, M., 2017, p. 5).

Essas contradições nos protestos podem ser compreendidas pelo fato de que não houve somente reivindicações para melhorias dos hospitais, escolas, moradias, o que poderia sugerir uma aparente agenda "anti neoliberal" (SILVA, M. 2017). Também houve reivindicações com o estandarte de movimentos que pregavam antipartidarismo e antipolíticos (SILVA, M. 2017), em especial, o coro "Fora PT", "Lula Ladrão" e "Fora Dilma”.

O movimento ESP, como eles próprio dizem, atuam desde 2004, é uma "[...] iniciativa contra o uso das escolas e universidades para fins de propaganda ideológica, política e partidária" (ESCOLA SEM PARTIDO, 2020). O movimento conseguiu emplacar quatro projetos de lei (PL) no Congresso Nacional, a de números 7180/2014, $867 / 2015,193 / 2016$ e 246/2019.

A PL 7180/2014 tem como objetivo alterar o art. $3^{\circ}$ da Lei $n^{\circ} 9.394$, de 20 de dezembro de 1996, para incluir entre os princípios do ensino "o respeito às convicções do aluno, de seus pais ou responsáveis, dando precedência aos valores de ordem familiar sobre a educação escolar nos aspectos relacionados à educação moral, sexual e religiosa" (CÂMARA DOS DEPUTADOS, 2014). A PL 7180/2014 tinha sido arquivada no final da $54^{\text {a }}$ legislatura, mas foi desarquivada em 2015. Como não conseguiu ser votado, em virtude dos embates travados nas comissões, o projeto foi arquivado no final da $55^{\mathrm{a}}$ legislatura. Todavia, com a $56^{\mathrm{a}}$ legislatura e a eleição do presidente Bolsonaro (2019-), o projeto foi desarquivado e encontra-se em tramitação. (CÂMARA DOS DEPUTADOS, 2014).

A PL 193/2016 almejava incluir na Lei no 9.394/1996, o "Programa Escola sem Partido", o qual estabelecia novos princípios educacionais, dever dos professores e entre outras regulamentações que visam criminalizar o professor pelo trabalho pedagógico que contraria os novos princípios e deveres educacionais (SENADO FEDERAL, 2016). O projeto foi arquivado, mas se encontra sob nova numeração $246 / 2019$, apensado ao 867/2015 (CÂMARA DOS DEPUTADOS, 2019).

A resistência do movimento ESP demonstram que procuram operar como uma revolução passiva, constituindo assim

\footnotetext{
[...] um dos fenômenos mais significativos do [neo]conservadorismo que vem crescendo politicamente no Brasil. O movimento se constitui na articulação de diversos segmentos sociais, entre os quais militantes de extrema direita, como o MBL [Movimento Brasil Livre], e setores religiosos, que visa criar mecanismos de controle contra professores que supostamente fazem doutrinação ideológica nas escolas. Essa censura aos espaços institucionais de ensino teria como objetivo garantir que a educação seja feita de forma neutra, sem que uma corrente ideológica possa se sobrepor a outras. Em termos práticos, significaria proibir a reflexão crítica nos espaços escolares, moldando crianças e jovens para que não problematizem a realidade em que estão inseridos. (GOULART DA SILVA, 2019, p. 169-170).
}

Na elaboração do PNE 2014-2024, a situação não foi diferente, o movimento ESP esteve presente e atuante junto com os grupos fundamentalistas religiosos para 
combater diretrizes que fariam inserção da discussão de gênero e diversidade sexual nas escolas (MARTINS DE OLIVEIRA; OLIVEIRA, 2018). Além do lobby de empresários da área da educação, intelectuais orgânicos à burguesia partiram para o embate na formulação do PNE, com objetivo de garantir a publicização da educação.

Como Minto (2018, p. 6) ensina,

\begin{abstract}
Na elaboração de uma peça como o PNE, abre-se a possibilidade de alterar as linhas gerais de implementação das políticas para a educação. Para o setor privado, representa uma possibilidade de reorganização dos seus interesses perante o Estado, mormente de ampliar as estratégias de captura do fundo público num contexto em que os serviços se tornam cada vez mais estratégicos para frações da burguesia brasileira.
\end{abstract}

Assim, neoconservadores e neoliberais participaram em conjunto na elaboração do novo PNE, visando definir os rumos da educação. Houve resistências de grupos considerados progressistas e de intelectuais orgânicos à classe operária. Dessa maneira, o documento final apresentou ambiguidades, contradições e desafios que necessitam ser superados por novas políticas públicas educacionais e no trabalho pedagógico das escolas.

A elaboração da BNCC (2013-2018) também foi objeto de disputa tanto pelos neoconservadores quando pelos neoliberais. Conforme Silva (2019), a instituição e implementação de uma BNCC vinha sendo debatida por diversas organizações da sociedade civil e sociedade política, com a finalidade de regulamentar, instituir e assegurar o direito à educação a todos os brasileiros. Apesar dessa finalidade, a construção da BNCC foi realizada em um ciclo conjuntural (2013-2018) de crise do capital que interferiu fortemente na política brasileira, o que levou a crises dentro do Ministério da Educação. A BNCC somente foi aprovada após o impeachment de Dilma Rousseff (2015-6), em 31 de agosto de 2016, e sob a presidência a Michel Temer (2016- 2018). (SILVA, 2019).

\footnotetext{
Poucas semanas depois, o Governo Temer emitia a Medida Provisória n ${ }^{\circ}$ 746, de 22 de setembro de 2016, redefinindo de forma autocrática todo o sistema educacional brasileiro. A Medida Provisória redefiniu todos os parâmetros e discussões acerca da concepção de BNCC a ser adotada, de tal forma a definir um Documento antidemocrático e antipopular, em todos os seus aspectos.

Com o Golpe de Estado de tipo Parlamentar-Judicial-Midiático de 2016, a condução da BNCC se deu de forma autocrática, sob o comando da Gestão Mendonça Filho/Maria Helena Guimarães de Castro. No caso, o Ministro emitiu a Portaria $n^{\circ}$ 790, de 27 de julho de 2016, instituindo o Comitê Gestor da Base Nacional Curricular Comum e Reforma do Ensino Médio, delegando plenos poderes à Maria Helena Guimarães de Castro, para conduzir a contrarreforma da educação [...] (SILVA, 2019, p. 87).
}

Portanto, a terceira e última versão da BNCC, foi elaborada no governo Temer, logo após o Golpe de Estado Soft, e estava vinculada a concepção neoliberal-flexível extremada, privatista e avessa à participação e representação popular, porque o objetivo era dar cabo ao programa de contrarreformas imposto pelo capital (SILVA, M., 2019; 2017). Este programa de contrarreformas do capital, capitaneado por diversas agências multilaterais, "[...] não passaria pelo crivo das urnas, bem como o Partido dos Trabalhadores teria imensas dificuldades para aprová-lo, devido sua origem e 
compromisso com frações importantes das classes trabalhadoras e demais classes subalternas [...]"' (SILVA, M., 2017, p. 8).

No que tange à distribuição das teses e dissertações por instituição e programa de pós-graduação (tabela 3), verifiquei a predominância $(n=3)$ de trabalhos defendidos na UFPB, o que corresponde a $27 \%$ de participação dentre nove instituições de ensino superior (IES). Outras oito IES participaram uma única vez. Tal participação irrisória sinaliza que o tema neoconservadorismo no campo da educação não foi consolidado nas IES, embora a preocupação com a atuação do neoconservadorismo nas políticas educacionais esteve presente nos últimos quatro anos.

Tabela 3 - Distribuição dos trabalhos por instituição e programa de pós-graduação

\begin{tabular}{|c|c|c|}
\hline INSTITUIÇÕES & $\begin{array}{c}\text { PROGRAMAS DE } \\
\text { PÓS- GRADUAÇão }\end{array}$ & N. $^{{ }^{*} \text { TRABALHOS }}$ \\
\hline Univ. Fed. da Paraíba (UFPB) & Serviço Social & 2 \\
\cline { 2 - 3 } & Educação & 1 \\
\hline Univ. Estadual de Campinas (Unicamp) & Educação & 1 \\
\hline $\begin{array}{c}\text { Pontifícia Universidade Católica - Goiás } \\
\text { (PUC-GO) }\end{array}$ & Serviço Social & 1 \\
\hline Univ. Estadual da Paraíba (UEPB) & Serviço Social & 1 \\
\hline Univ. Estadual do Ceará (UECE) & Serviço Social & 1 \\
\hline Universidade Passo Fundo (UPF) & Educação & 1 \\
\hline Univ. Fed. do Alagoas (UFAL) & Ensino da Saúde & 1 \\
\hline Universidade Estadual Paulista Júlio de \\
Mesquita Filho (Unesp) & Serviço Social & 1 \\
\hline Univ. Fed. do Acre (UFAC) & Educação & $\mathbf{1 1}$ \\
\hline & Total & 1 \\
\hline
\end{tabular}

Fonte: Elaboração do autor.

Nos trabalhos publicados em artigos foram encontradas 34 instituições de ensino diferentes, com participação em média de um trabalho por instituição. As instituições que tiveram mais presentes, duas ou três vezes, foram a Universidade Federal de Santa Catarina (UFSC), Universidade Federal do Rio Grande do Sul (UFRGS), Universidade Federal Fluminense (UFF), Universidade do Estado do Rio de Janeiro (UERJ), Unicamp, Unesp, Universidade Regional de Blumenau, Universidad Nacional de la Pampa. Dentre as 34 instituições, 27 eram brasileiras, majoritariamente das regiões Sudeste e Sul, e sete instituições estrangeiras de quatro países (Argentina, Portugal, Espanha, Inglaterra). Aliás, na área de formação dos 42 autores de artigos predominava a Educação $(n=31)$, seguido da Sociologia $(n=4)$, Direito $(n=3)$, Filosofia $(=3)$ e Psicologia $(n=1)$. Em resumo, a área de formação dos autores pesquisadores, pertencentes a área de Educação, representou 74\% do total.

Em relação aos periódicos que tiveram publicações relacionados ao tema investigado, identifiquei 19 revistas e uma coletânea de Anais do $2^{\circ}$ Colóquio Habermas e $3^{\circ}$ Colóquio de Filosofia da Informação (2016). O periódico que recebeu maior número de trabalhos foi a Educação \& Sociedade $(\mathrm{n}=5)$, seguido da Educação \& Pesquisa (n=2), Ciência \& Educação $(n=2)$, Revista Lusófona da Educação $(n=2)$. 
Outros 15 periódicos tiveram um trabalho cada. Inclusive, predomina trabalhos publicados na área de conhecimento em Educação - Educação $(n=20)$, Educação Especial $(n=1)$, Educação Física $(n=1)$-, ou seja, corresponde a $81 \%$ do total de trabalhos. Também houve trabalhos publicados na área do Direito $(n=2)$, Filosofia $(n=2)$ e Administração $(\mathrm{n}=1)$.

Os dados acima podem ser contrastados com a tabela 3 que chama atenção para o fato de que quase a metade das dissertações/teses foram produzidas em programas da área do Serviço Social $(n=6)$, seguido da Educação $(n=4)$ e Ensino de Saúde $(n=1)$. A presença significativa do Serviço Social pode estar relacionada a dois fatores: a) o assistente social tem como função a defesa de direitos e a implementação de políticas públicas; b) o assistente social faz parte de campo profissional interdisciplinar Assistência Social, Saúde e Educação.

Em relação às dependências administrativas dessas instituições de ensino superior, três são federais (UFPB, UFAL, UFAC), quatro estaduais (Unicamp, UEPB, UECE, Unesp) e duas particulares (PUC-GO e UPF). Essas nove instituições estão distribuídas nas cincos regiões do país: Nordeste $(n=6)$, Sudeste $(n=2)$, Centro-Oeste $(n=1)$, Sul $(n=1)$, Norte $(n=1)$, reproduzindo, assim, a distribuição da pós-graduação brasileira quase no sentido inverso da concentração de programas de pós-graduação nas regiões Sul e Sudeste. De acordo com os dados da Capes (2018), as regiões Sul e Sudeste aglomeram quase $3 / 4$ de programas de pós-graduação, ao passo que a Região Nordeste apresenta números de programas abaixo dessas regiões. Tal situação leva a questionar: por que as regiões mais ricas e populosas do Brasil optaram por publicar pesquisas relacionadas ao neoconservadorismo no campo da educação em periódicos? Por que pesquisadores da Região Nordeste não tiveram participação semelhante na divulgação de seus trabalhos em formato de artigo para periódicos? Haveria também desigualdades escolares e científicas que tendem a reproduzir desigualdades acadêmicas e científicas, em termos de financiamentos de pesquisa?

Portanto, as 38 produções acadêmicas divulgadas entre 2002-2019, encontramse em sua grande maioria filiadas à área da Educação (35 autores no total, 66\%). Este dado aponta que os autores de artigos buscam atender as exigências da Capes na escolha dos periódicos, publicar textos conforme os critérios de avaliação dos cursos de graduação e pós-graduação.

\section{Neoconservadorismo e a Educação}

Com o objetivo de identificar a temática dos trabalhos publicados entre 20022019, foram analisadas as três principais palavras-chaves atribuídas pelos autores. Conforme a tabela 4 , notei que as temáticas mais frequentes - mencionada duas vezes no mínimo - correspondem a $65,80 \%$, enquanto as temáticas isoladas representam $34,20 \%$.

Tabela 4 - Temas dos trabalhos

\begin{tabular}{|c|c|c|}
\hline TEMAS & $\begin{array}{c}\text { QUANTIDADE DE } \\
\text { PALAVRAS-CHAVES }\end{array}$ & EQUIVALÊNCIA \\
\hline Educação & 13 & $11,40 \%$ \\
\hline Neoconservadorismo & 10 & $8,60 \%$ \\
\hline
\end{tabular}




\begin{tabular}{|c|c|c|}
\hline Política educacional & 9 & $7,80 \%$ \\
\hline Educação superior & 7 & $6 \%$ \\
\hline Serviço social & 6 & $5,50 \%$ \\
\hline Democracia & 5 & $4 \%$ \\
\hline Ensino religioso & 4 & $3,60 \%$ \\
\hline Avaliação & 4 & $3,60 \%$ \\
\hline Globalização & 3 & $2,60 \%$ \\
\hline Formação profissional & 3 & $2,60 \%$ \\
\hline Currículo & 3 & $2,60 \%$ \\
\hline Gênero & 2 & $1,75 \%$ \\
\hline Base Nacional Curricular Comum & 2 & $1,75 \%$ \\
\hline Modernização conservadora & 2 & $1,75 \%$ \\
\hline Formação docente & 2 & $1,75 \%$ \\
\hline $\begin{array}{l}\text { Biologia, crise financeira internacional, } \\
\text { direitos, discurso, educação à distância, } \\
\text { Educação baseada em competências, } \\
\text { educação de jovens e adultos, educação } \\
\text { médica, educação profissional, ensino de } \\
\text { arte, ensino de ciências, epistemologia, } \\
\text { escola sem partido, Estado de Bem-Estar, } \\
\text { Europa, gestão acadêmica, governança } \\
\text { educacional, governo, Habermas, } \\
\text { hegemonia, história da educação, } \\
\text { linguagem, modernidade, multiculturalismo, } \\
\text { neoliberalismo, parcerias público-privadas, } \\
\text { pedagogia histórico-crítica, planejamento, } \\
\text { plano municipal de educação, pós- } \\
\text { modernidade, privatização, projeto político- } \\
\text { pedagógico, reformas de ensino, } \\
\text { sindicalismo, supervisão de estágio, teatro, } \\
\text { teoria do capital humano, teoria pedagógica, } \\
\text { trabalho docente } \\
\text { (n=1) }\end{array}$ & 39 & $34,20 \%$ \\
\hline $\begin{array}{c}\text { TOTAL } \\
\end{array}$ & 114 & $100,00 \%$ \\
\hline
\end{tabular}

Fonte: elaboração do autor.

A temática "Educação" e "Neoconservadorismo" demarcaram um espaço importante, confirmando o objetivo estabelecido neste estudo e a assertividade da escolha dos critérios. Além de evidenciar que que a educação é um campo interligado as ciências humanas e sociais. Também verifico que os temas política educacional e educação superior tem sido privilegiados pelos autores, porque fazem parte da atuação de grupos da sociedade civil que tem interferido nas dinâmicas do Estado.

O tema Serviço Social, à primeira vista, pode aparecer alheio à educação, todavia, Barroco (2011) demonstra que o assistente social, em sua formação e atuação profissional vem sofrendo desregulamentação, desvalorização e precarização do trabalho, falta de preparo técnico e teórico, fragilização de uma consciência crítica e política etc. 


\begin{abstract}
A ideologia neoconservadora tende a se irradiar nas instituições sob formas de controle pautadas na racionalidade tecnocrática e sistêmica tendo por finalidade a produtividade, a competitividade e a lucratividade, onde o profissional é requisitado para executar um trabalho repetitivo e burocrático, pragmático e heterogêneo, que não favorece atitudes críticas e posicionamentos políticos. Instituições voltadas para a coerção, como prisões, delegacias, casas para jovens infratores, abrigos, instituições jurídicas, demandam ao assistente social atividades de controle e censura: avaliações de situações que envolvem os sujeitos criminalizados moralmente e julgados como irrecuperáveis pelo poder dominante. A ideologia dominante está incorporada nessas instituições de diversas formas, como mostram vários estudos (Wacquant, 2007; Batista, 2003a, 2003b). O discurso dominante é o da naturalização e moralização da criminalidade; as práticas de encaminhamento são seletivas, baseadas, muitas vezes, em critérios que envolvem avaliações morais, de classe e condição social. O assistente social precisa estar capacitado para enfrentar esse discurso, de forma a não reproduzi-lo reeditando o conservadorismo profissional, a não atender às novas requisições do estado policial, para não incorporá-las exercendo a coerção. Esse enfrentamento ético-político supõe estratégias coletivas de capacitação e organização política, de discussão nos locais de trabalho, de articulação com outras categorias, entidades e com os movimentos organizados da população usuária (BARROCO, 2011, p. 213-214).
\end{abstract}

Os temas presentes nos trabalhos também sinalizam que as ideologias neoconservadoras ocupam espaços em diferentes âmbitos da atuação da sociedade política e sociedade civil. Na sociedade política, as discussões envolvem parcerias público-privada, reformas estruturais dos Estados, representações partidárias e sindicais, entre outras. Com base em Gramsci (2014, 2007, 2001), penso que as ideologias orgânicas à classe burguesa têm permeado as decisões da sociedade política. Inclusive, desde as manifestações de junho de 2013 houve a conformação do bloco histórico no Estado, com a atuação de intelectuais orgânicos e partidos vinculados ao capital, para implementar as contrarreformas neoliberais.

$\mathrm{Na}$ sociedade civil (escolas e universidades), a atuação dos neoconservadores está relacionada aos seguintes aspectos: fundamentos da educação; formação de professores; políticas curriculares e de avaliação; modalidades de ensino; formulação e implementação de políticas educacionais; administração escolar; trabalho pedagógico; orientação e diversidade sexual na escola; ensino religioso e relação público-privado. Tais aspectos corroboram com a pesquisa de Prendergast, Hill e Jones (2017) sobre o movimento do neoconservadorismo na educação apresentados na introdução.

Aliás, os temas da tabela 4 confirmam que a agenda neoliberal e neoconservadora para a educação está sendo analisada pelos pesquisadores, em especial, incluo a construção e implementação da BNCC e do novo PNE. A escola é alvo dos neoconservadores porque ela "[...] é o instrumento para elaborar os intelectuais de diversos níveis" (GRAMSCI, 2001, p. 19). Embora a palavra-chave "Escola Sem Partido" apareça uma única vez, a pauta do movimento fez se presente, por exemplo, na defesa do ensino obrigatório do criacionismo nas escolas e do respeito à religião da família e suas convicções sociais pela escola. Na verdade, a pauta do ESP é de garantir que as ideologias orgânicas do seu grupo sejam implementadas nas instituições de ensino. 
Então, a realidade abordada nos estudos faz refletir que continuamos a lidar com uma luta de classes e que possui um elemento neoliberal, econômico. O neoliberalismo abraçou um elemento político neoconservador para impor, proteger e controlar as resistência contra o capital, inclusive, impor sua agenda nas escolas e sociedade (PRENDERGAST; HILL; JONES, 2017).

\section{CONSIDERAÇÕES FINAIS}

A produção científica disseminada em periódicos e programas de pós-graduação no Brasil sobre neoconservadorismo no campo da educação esboça um retrato dos interesses de pesquisa. Narra história de uma produção com autorias individuais, em sua maioria, e não sinaliza um campo consolidado de pesquisas relacionadas ao neoconservadorismo na área educacional. As fontes demonstram que $o$ neoconservadorismo representa uma aguda crise do capitalismo. Este se reestrutura para dar continuidade à exploração e acumulação do capital. Assim, os intelectuais neoconservadores aproveitam-se da ideologia do capital para ser beneficiados de forma econômica e moralmente, numa aliança entre liberdade e moralidade social tradicional ou, como Apple (2003), designa: modernização conservadora.

Em termos teóricos, considero que a universidade é uma sociedade civil fundamental para analisar o contexto atual e intercambiar projetos e formação com os professores da educação básica. A onda neoconservadora vem disputando a hegemonia pela direção e domínio na educação. Há resistências por parte de professores, alunos e comunidade escolar. Embora, algumas dessas resistência não se trata de romper com o modo de produção capitalista.

Os temas dos trabalhos demonstram que o neoliberalismo exerce uma hegemonia nas políticas educacionais e no trabalho escolar. O neoconservadorismo disputa a hegemonia no campo educacional. Dessa aliança resulta que os intelectuais orgânicos vinculados à burguesia visam cimentar suas ideologias no espaço escolar, para isso recorre a criação de leis e a revogação de dispositivos jurídicos que enfrentariam a moralidade tradicional. Ante essa cenário, é preciso conhecer melhor os intelectuais dos grupos neoconservadores, bem como mapear a sua atuação no Estado e construir estratégias coletivas, democráticas e participativas, mediante uma revolução permanente a ser realizada pela classe trabalhadora.

Em termos metodológicos, os objetivos e as técnicas de coleta e análise de dados propiciaram conhecer a configuração da produção científica sobre o tema proposto. Mas recomendo complementar as fontes de dados com os trabalhos em anais de eventos, livros e capítulos de livros, para melhor compreensão do panorama científico brasileiro. Ampliação de busca de dados em periódicos internacionais podem contribuir no aprofundamento do neoconservadorismo na educação. Também é possível fazer a leitura integral dos textos para investigar as epistemologias e métodos de pesquisa empregados, os quais servirão para desenhar novos projetos de pesquisa.

Portanto, as lutas de classes e as contradições sociais, políticas e educacionais atravessa os trabalhos das instituições de ensino e as investigações científicas. A ciência e a filosofia da práxis são as concepções de mundo que podem identificar no neoconservadorismo o senso comum, as ideologias arbitrárias e orgânicas, as ações da sociedade civil e sociedade política. 


\section{REFERÊNCIAS}

APPLE, M. W. Educando à direita: mercados, padrões, Deus e desigualdade. Tradução de Dinah de Abreu Azevedo. São Paulo: Cortez: Instituto Paulo Freire, 2003.

BARROCO, Maria Lucia S. Barbárie e neoconservadorismo: os desafios do projeto ético-político. Serv. Soc. Soc. São Paulo, n. 106, p. 205-218, jun. 2011. Disponível em $<$ http://www.scielo.br/scielo.php?script=sci_arttext\&pid=S0101-

$66282011000200002 \& \operatorname{lng}=e n \& n r m=i s o>$. Acesso em: 05 de maio de 2020.

BRANDÃO, N. A.; DIAS, E. F. A questão da ideologia em Antonio Gramsci. Revista Trabalho \& Educação, UFMG, Belo Horizonte, v. 16, n. 2, p. 81-98, jul./dez. 2007.

CÂMARA DOS DEPUTADOS. PL 246/2019. Disponível em:

$<$ https://www.camara.leg.br/proposicoesWeb/fichadetramitacao?idProposicao $=2190752$ >. Acesso em: 03 de maio de 2020.

CÂMARA DOS DEPUTADOS. PL 7180/2014. Disponível em:

$<$ https://www.camara.leg.br/proposicoesWeb/fichadetramitacao?idProposicao $=606722>$ . Acesso em: 03 de maio de 2020.

CENTRO DE ESTUDOS DE EDUCAÇÃO E SOCIEDADE (Cedes). Educação \& Sociedade. Disponível em:

$<$ http://www.scielo.br/scielo.php?script=sci_serial\&pid=0101-

7330\&lng=en\&nrm=iso>. Acesso em: 21 abr. 2020.

COORDENAÇÃO DE APERFEIÇOAMENTO DE PESSOAL DE NÍVEL SUPERIOR (Capes). Portal de Periódicos. Disponível em: <https://www.periodicos.capes.gov.br/ \. Acesso: abr. 2020a.

COORDENAÇÃO DE APERFEIÇOAMENTO DE PESSOAL DE NÍVEL SUPERIOR (Capes). Catálogo de Teses e Dissertações. Disponível em:

<https://catalogodeteses.capes.gov.br/catalogo-teses/\#!/ >. Acesso: abr. 2020b.

CAPES. GEOCAPES - Sistema de Informações Georreferenciadas. Dados de 2018. Disponível em: <https://geocapes.capes.gov.br/geocapes/>. Acesso em: 21 abr. 2020.

DI FRANCO, M. G.; DI FRANCO, N. B.; SIDERAC, S. A formação docente nas políticas públicas: o campo das práticas como a possibilidade. Praxis \& Saber, v. 7, n. 15, p. 17-40, 2016. 
ESCOLA SEM PARTIDO. Home. Disponível em: <http://escolasempartido.org/>. Acesso em: 03 de maio de 2020.

GOULART DA SILVA, M. O Escola Sem Partido como expressão do ideário militar. Germinal: Marxismo e Educação em Debate, Salvador, v. 10, n. 3, p. 169-175, mai. 2019. Disponível em:

$<$ https://portalseer.ufba.br/index.php/revistagerminal/article/view/28612>. Acesso em: 02 de maio de 2020.

GRAMSCI, A. Cadernos do cárcere - volume 1: introdução ao estudo da filosofia; a filosofia de Benedetto Croce. 7. ed. Trad. de Carlos Nelson Coutinho; coedição de Luiz Sérgio Henriques e Marco Aurélio Nogueira. Rio de Janeiro: Civilização Brasileira, 2014.

GRAMSCI, A. Cadernos do cárcere - volume 3: Maquiavel; notas sobre o Estado e a política. 3. ed. Trad. de Carlos Nelson Coutinho; coedição de Luiz Sérgio Henriques e Marco Aurélio Nogueira. Rio de Janeiro: Civilização Brasileira, 2007.

GRAMSCI, A. Cadernos do cárcere - volume 2: os intelectuais; o princípio educativo; jornalismo. 2 ed. Trad. de Carlos Nelson Coutinho; coedição de Luiz Sérgio Henriques e Marco Aurélio Nogueira. Rio de Janeiro: Civilização Brasileira, 2001.

GRUPPI, L. Conceito de Hegemonia em Gramsci. 2. ed. Tradução de Carlos Nelson Coutinho. Rio de Janeiro: Editora Graal, 1980.

HAYASHI, M. C. P. I. H. Análise bibliométrica: leituras teóricas, procedimentos metodológicos e protocolo de coleta de dados. São Carlos, 2014. (mimeo).

HAYASHI, M. C. P. I.; MUGNAINI, R.; HAYASHI, C. R. M. (Org.). Bibliometria e cientometria: metodologia e aplicações. São Carlos: Pedro e João Editores, 2013.

HUNTINGTON, S. P. Robust Nationalism. The National Interest, New York: The Nixon Center, n. 58, inverno de 1999, p. 37. Disponível em:

<https://nationalinterest.org/article/robust-nationalism-698.. Acesso em: 02 maio 2020.

INSTITUTO BRASILEIRO DE INFORMAÇÃO PARA CIÊNCIA E TECNOLOGIA (IBICT). Oasisbr. Disponível em: <http://oasisbr.ibict.br/vufind/>. Acesso: abr. 2020a.

INSTITUTO BRASILEIRO DE INFORMAÇÃO PARA CIÊNCIA E TECNOLOGIA (IBICT). Biblioteca Digital de Teses e Dissertações. Disponível em:

$<$ http://bdtd.ibict.br/vufind/>. Acesso: abr. 2020b. 
LEHER, R.; VITTÓRIA, P.; MOTTA, V. C. Educação e mercantilização em meio à tormenta político-econômica do Brasil. Germinal: Marxismo e Educação em Debate, Salvador, v. 9, n. 1, p. 14-24, mai. 2017. Disponível em:

<https://portalseer.ufba.br/index.php/revistagerminal/article/view/21792>. Acesso em: 01 de maio de 2020.

LIMA, I. G. de; HYPOLITO, A. M. A expansão do neoconservadorismo na educação brasileira. Educação \& Pesquisa, São Paulo, v. 45, 2019. Disponível em $<$ http://www.scielo.br/scielo.php?script=sci_arttext\&pid=S151797022019000100567\&lng=en\&nrm=iso>. Acesso em: 13 abr. 2020.

MARTINS, M. F. Gramsci, os intelectuais e suas funções científico-filosófica, educativo-cultural e política. Pro-Posições, Campinas, v. 22, n. 3, p. 131-148. set./dez. 2011.

MARTINS, M. F. Sociedade civil e "terceiro setor": apropriações indébitas do legado teórico-metodológico de Gramsci. Revista de Filosofia Aurora, PUC-PR, v. 20, n. 26, p. 75-100. jan./jun. 2008.

MARTINS, M. F. Conhecimento e disputa pela hegemonia: reflexões em torno do valor ético-político e pedagógico do senso comum e da filosofia em Gramsci. LOMBARDI, José C.; SAVIANI, Dermeval. Marxismo e educação: debates contemporâneos. Campinas-SP: Autores Associados e HISTED-BR, 2005. p. 123-159.

MARTINS DE OLIVEIRA, A. L. A. R.; OLIVEIRA, G. G. S. de. Novas tentativas de controle moral da educação: conflitos sobre gênero e sexualidade no currículo e na formação docente. Educação Unisinos, São Leopoldo, v. 22, n. 1, p. 16-25, jan./mar. 2018. Disponível em: <http://www.revistas.unisinos.br/index.php/educacao/article/view/edu.2018.221.02>. Acesso em: 03 de maio de 2020.

MINAYO, M. C. de S.; SANCHES, O. Quantitativo-qualitativo: oposição ou complementaridade? Cad. Saúde Pública, Rio de Janeiro, v. 9, n. 3, p. 237-248, set. 1993. Disponível em: <http://www.scielo.br/scielo.php?script=sci_arttext\&pid=S0102311X1993000300002\&lng=en\&nrm=iso>. Acesso em: 02 de maio de 2020.

MINTO, L. W. Educação superior no PNE (2014-2024): apontamentos sobre as relações público-privadas. Rev. Bras. Educ., Rio de Janeiro, v. 23, 2018. Disponível em: <http://www.scielo.br/scielo.php?script=sci_arttext\&pid=S1413-

24782018000100208\&lng=en\&nrm=iso>. Acesso em: 03 de maio de 2020. 
MOCHOCOVITCH, L. G. Gramsci e a escola. 3. ed. São Paulo: Ática, 1992. (Série Princípios).

MOLL, R. Diferenças entre neoliberalismo e neoconservadorismo: duas faces da mesma moeda? UNESP, 2015. Disponível em: <http://ieei.unesp.br/portal/wpcontent/uploads/2016/11/Diferen\%C3\%A7as-entre-neoliberalismo-eneoconservadorismo.pdf $>$. Acesso em: 02 de maio de 2020.

PRENDERGAST, L. M.; HILL, D.; JONES, S. Social Exclusion, Education and Precarity: neoliberalism, neoconservatism and class war from above. Journal for Critical Education Policy Studies, v. 15, n. 2, p. 23-58, out. 2017. Disponível em: <http://www.jceps.com/archives/3526>. Acesso em: 02 de maio de 2020.

RED DE REVISTAS CIENTÍFICAS DE AMÉRICA LATINA Y EL CARIBE, ESPAÑA Y PORTUGAL (Redalyc). Sistema de Información Científica Redalyc Red de Revistas Científicas de América Latina y el Caribe. Disponível em:

<https://www.redalyc.org/>. Acesso: abr. 2020.

RIGOLIN, C. C. D.; HAYASHI, C. R. M.; HAYASHI, M. C. P. I. Métricas da participação feminina na ciência e na tecnologia no contexto dos INCTs: primeiras aproximações. Liinc em Revista, Rio de Janeiro, v. 9, p. 143-170, 2013. Disponível em: <http://revista.ibict.br/liinc/article/view/3400>. Acesso em: 02 maio 2020.

SENADO FEDERAL. Projeto de Lei do Senado $n^{\circ}$ 193, de 2016. Disponível em: <https://www25.senado.leg.br/web/atividade/materias/-/materia/125666 2 . Acesso em: 03 de maio de 2020.

SILVA, J. H. da. Mapeamento da produção científica veiculada em periódicos sobre a temática APAE (2000-2015). Perspec. Dial.: Rev. Educ. e Soc., Naviraí, v. 4, n. 7, p. 64-79, jan./jun. 2017. Disponível em:

<https://periodicos.ufms.br/index.php/persdia/article/view/2855>. Acesso em: 02 maio 2020.

SILVA, J. H. da; HAYASHI, M. C. P. I. Estudo bibliométrico da produção científica sobre a associação de pais e amigos dos excepcionais. Revista Educação Especial, Santa Maria, p. 65-80, mar. 2018. Disponível em:

<https://periodicos.ufsm.br/educacaoespecial/article/view/18170>. Acesso em: 02 maio 2020 .

SILVA, M. L. Notas gramscianas: golpe de estado e luta de classes no Brasil do século XXI. MovimentAção, v. 4, n. 07, p. 01-32, jul. 2017. Disponível em: 
<http://ojs.ufgd.edu.br/index.php/movimentacao/article/view/8427/4482>. Acesso em: 01 de maio de 2020.

SILVA, M. L. A base do golpe: a nova colonização pela captura da subjetividade. Germinal: Marxismo e Educação em Debate, Salvador, v. 11, n. 1, p. 74102, set. 2019 Disponível em:

<https://portalseer.ufba.br/index.php/revistagerminal/article/view/30693>. Acesso em: 01 maio de 2020.

STELMACHUK, A. C. da L.; HAYASHI, M. C. P. Análise bibliométrica sobre avaliação de pessoas com deficiência intelectual para ingresso em serviços de Educação Especial. REICE - Revista Iberoamericana sobre Calidad, Eficacia y Cambio en Educación, v. 13, n. 2, dez. 2015. Disponível em:

<https://revistas.uam.es/index.php/reice/article/view/2789>. Acesso em: 21 abr. 2020.

TANNURI DE OLIVEIRA, E. F.; GRACIO, M. C. Biblioteconomia e ciência da informação no Brasil: comparando indicadores bibliométricos entre países de destaque. HAYASHI, M. C. P. I.; MUGNAINI, R.; HAYASHI, C. R. M. (Org.). Bibliometria e cientometria: metodologia e aplicações. São Carlos: Pedro e João Editores, 2013. p. 7587.

TEIXEIRA, C. G. P. Quatro temas fundamentais do pensamento neoconservador em política externa. Rev. bras. polít. int., Brasília, v. 50, n. 2, p. 80-96, dez.

2007. Disponível em <http://www.scielo.br/scielo.php?script=sci_arttext\&pid=S003473292007000200006\&lng=en\&nrm=iso>. Acesso em: 02 de maio de 2020.

\section{Bibliografia Consultada}

\section{Dissertações e Teses (2004-2019)}

ALBUQUERQUE, J. E. B. de. Educação e democracia escola em tempos sombrios: neoconservadorismo na educação brasileira. Dissertação (Mestrado em Educação) Universidade de Passo Fundo, Passo Fundo, 2018.

ALMEIDA, C. C. A. As tendências pedagógicas na supervisão de estágio do curso de Serviço Social: a compreensão dos sujeitos. Tese (Doutorado em Serviço Social) Universidade Estadual Paulista Júlio de Mesquita Filho, Franca, 2019.

ARAÚJO, L. F. de. Diretrizes curriculares nacionais do curso de graduação em medicina: efeitos de sentidos da noção de competências. Dissertação (Mestrado em Ensino na Saúde) - Universidade Federal do Alagoas, Maceió, 2013. 
AVELAR, S. M. Formação profissional, fundamentos do serviço social e ofensiva conservadora na educação superior - a expansão dos cursos de Serviço Social no Estado de Goiás. Dissertação (Mestrado em Serviço Social) - Pontifícia Universidade Católica de Goiás, Goiânia, 2019.

CUNHA, A. D. da. Tendências teórico-metodológicas da formação profissional em serviço social no ensino à distância na Paraíba. Dissertação (Mestrado em Serviço Social), Universidade Federal da Paraíba, João Pessoa, 2018.

HONORATO, R. F. de S. Gênero nas políticas educacionais da educação de jovens e adultos: trajetória, influências e textos. Dissertação ( Mestrado em Educação) Universidade Federal da Paraíba, João Pessoa, 2018.

MOREIRA, A. L. G. O plano municipal de educação do município de Rio Branco/Acre como planejamento de políticas públicas no decênio (2015-2025): um estudo de seu processo de elaboração e concepção. Dissertação (Mestrado em Educação) Universidade Federal do Acre, Rio Branco, 2018.

MOURA, V. G. G. A direção da formação profissional em serviço social: uma análise do projeto político-pedagógico do curso de serviço social na universidade estadual da Paraíba. Dissertação (Mestrado em Serviço Social) - Universidade Estadual da Paraíba, Campina Grande, 2016.

PINHEIRO, P. W. M. Serviço Social e neoconservadorismo religioso: a percepção dos/as estudantes e os desafios para projeto ético-político. Dissertação (Mestrado em Serviço Social) - Universidade Estadual do Ceará, Fortaleza, 2013.

PITON, I. M. Políticas educacionais e movimento sindical docente: reformas educativas e conflitos docentes na educação básica paranaense. Tese (Doutorado em Educação) Universidade Estadual de Campinas, Campinas, 2004.

RIBEIRO, H. M. B. Avanço do neoconservadorismo no Serviço Social: uma análise a partir das Diretrizes Curriculares da ABEPSS. Dissertação (Mestrado em Serviço Social) - Universidade Federal do Paraíba, João Pessoa, 2017.

$\underline{\text { Artigos (2002-2019) }}$

BIESTA, G. Medir o que valorizamos ou valorizamos o que medimos? Globalização, responsabilidade e noção de propósito da educação. Revista Educação Especial, v. 31, n. 63 , p. $815-831,2018$. 
CANDIOTTO, C. Aproximações entre capital humano e qualidade total na educação. Educ. rev., Curitiba, n. 19, p. 199-216, jun. 2002.

DA SILVA, M. R.; PIRES, G. de L.; PEREIRA, R. S. A Base Nacional Comum Curricular da Educação Básica em tempos de neoconservadorismo e de "neoliberalismo que saiu do armário"; mas também de tempos de resistência: Fora Temer!!! Motrivivência, Florianópolis, v. 28, n. 48, p. 07-14, set. 2016.

DI FRANCO, M. G.; DI FRANCO, N. B.; SIDERAC, S. A formação docente nas políticas públicas: o campo das práticas como a possibilidade. Praxis \& Saber, v. 7, n. 15, p. 17-40, 2016.

DIAS SOBRINHO, J. Avaliação ética e política na função da educação como direito público ou como mercadoria ? Educ. Soc., v. 25, n. 88, p. 703-725, 2004.

DICKMANN, I.; CECCHETTI, E. Educação no Brasil em tempos de neoconservadorismo: desafios e desabafos sobre um futuro próximo! Revista Pedagógica, Chapecó, v. 20, n. 45, p. 7-10, set./dez. 2018.

FRIGOTTO, G.; CIAVATTA, M. Educação básica no Brasil na década de 1990: subordinação ativa e consentida à lógica do mercado. Educ. Soc., Campinas, v. 24, n. 82, p. 93-130, abr. 2003.

GALLO, S. Modernidade/pós-modernidade: tensões e repercussões na produção de conhecimento em educação. Educ. Pesqui., São Paulo, v. 32, n. 3, p. 551-565, dez. 2006

GONÇALVES, J. C. Verbo-visualidades e características em diálogo: produção de sentidos para o conhecimento em arte e partir da arte. Revista Lusófona de Educação, n. 28, p. 87-100, 2014.

HAAS, C. M. Educação superior no Brasil e os condicionamentos para políticas nacionais: impactos da aplicação transnacional na gestão universitária. Laplage em Revista, Sorocaba, v. 3, n. 3, p. 115-132, 2017.

LIMA, C. R. M. (Org.). Conflitos contemporâneos: direitos humanos e solidariedade. Anais XII Colóquio Habermas e III Colóquio de Filosofia da Informação. Rio de Janeiro: IBICT/Salute, 2016. 
LIMA, I. G. de; HYPOLITO, A. M. A expansão do neoconservadorismo na educação brasileira. Educ. Pesqui., São Paulo, v. 45, ago. 2019.

LIMA FILHO, D. L. Expansão da educação superior e da educação profissional no Brasil: tensões e perspectivas. Revista Educação em Questão, Natal, v. 51, n. 37, p. 195-223, 2015.

LOPES DE LIMA, J. F. Escola, formação humana e contribuição pedagógica do Dermeval Saviani no cenário contemporâneo. Roteiro, Joaçaba, v. 44, n. 2, p. 1-26, jul. 2019.

OLIVIERO, M.; CRUZ, P. M. Reflexões sobre a crise financeira internacional e o Estado de Bem-Estar. Revista Quaestio Juris, Rio de Janeiro, v. 7, n. 1, 2014.

PACHECO, J. A. Processos e práticas de educação e formação: Para uma análise da realidade portuguesa em contextos de globalização. Rev. Port. de Educação, Braga, v. 22, n. 1, p. 105-143, 2009.

PAVAN, R. Currículo e multiculturalismo: reflexões para a formação de educadores. Revista Lusófona de Educação, n. 15, p. 125-135, 2010.

PINHEIRO, M. A “crise da educação" em tempos de neoconservadorismo: a contribuição da história da educação para compreender o presente. Cadernos do GPOSSHE On-line, Fortaleza, v. 2, n. 1, p. 120-142, 14 ago. 2019.

PINTO, I. R.; ADRIÃO, T.; ALMEIDA, L. C. Crise do projeto democrático de educação. Educ. Soc., Campinas, v. 38, n. 140, p. 531-535, julho de 2017.

PINTO, I. R.; ADRIÃO, T.; ALMEIDA, L. C. Neoconservadorismo, educação e privação de direitos. Educ. Soc., Campinas, v. 38, n. 141, p. 865-872, dez. 2017.

ROBERTSON, S.; VERGER, A. A origem das parcerias público-privadas na governança global da educação. Educ. Soc., Campinas, v. 33, n. 121, p. 1133-1156, dez. 2012.

SELLES, S. E. A polêmica instituída entre ensino de evolução e criacionismo: dimensões do público e do privado no avanço do neoconservadorismo. Ciênc. educ., Bauru, v. 22, n. 4, p. 831-835, dez. 2016. 
SELLES, S. E.; DORVILLÉ, L. F. M.; VAHIA PONTUAL, L. Ensino religioso nas escolas estaduais do Rio de Janeiro: implicações para o ensino de ciências/biologia. Ciênc. educ., Bauru, v. 22, n. 4, p. 875-894, 2016.

SEVERO, R. G.; ESTRADA, R. D. Entrevista com Michael Apple. Educ. rev., Belo Horizonte, v. 35, 2019.

SOUZA JUNIOR, P. R. A influência do neoconservadorismo nos estudos de gênero no Brasil. Revista de Gênero, Sexualidade e Direito, Belém, v. 5, n. 2, p. 55-73, jul./dez. 2019.

TIRADENTES DOS SANTOS, A. de F. Política educacional para uma universidade microondas: gestão universitária, trabalho docente e qualidade da formação humana sob o efeito do "mercado educador". Revista Gestão Universitária na América Latina GUAL, Florianópolis, v. 3, n. 1, p. 1-16, 2010.

VILMAR DOS SANTOS, J.; SOUZA, O.; SELPA HEINZLE, M. R.; TORRES KATH, R. C. O status de bem público e democrático nas estatísticas públicas. Educação, v. 42, n. 1, p. 138-149, 2019.

Recebido:07/05/2020

Aprovado: 13/07/2020 